\title{
The Concept of Mediation as Protection of Fishery Resources from IUU Fishing Practices in Indonesia
}

Mansur Armin Bin Ali ${ }^{*}$

Faculty of Law, Tadulako University, Indonesia

DOI: $10.36348 /$ jaep.2021.v05i02.002

| Received: 21.01.2021 | Accepted: 08.02.2021 | Published: 10.02.2021

*Corresponding author: Mansur Armin Bin Ali

\section{Abstract}

This paper specifically analyzes the concept of mediation as protection of fishery resources from IUU fishing practices in Indonesia. The type of research used is normative legal research with a statutory approach, The data used are secondary data collected through literature search and document study. The collected data were then analyzed qualitatively. The results show that in the future it is necessary to seek legal breakthroughs so that the IUU Fishing law enforcement process has benefits, the KPKNL as an extension of the Ministry of Finance of the Republic of Indonesia has an interest to streamline options other than annihilating (auctions, grants, other uses) so that it has benefits for the state to conduct mediation by how to bring together investigators (as representatives of the state, it is the state that is the victim of crime because they have suffered losses due to stolen fisheries resources) with the perpetrator/ship owner (the party who committed the crime) The importance of mediation is to prevent investigators from taking the option of sinking the ship (sinking the ship), because if this is done (the investigator takes the option to destroy), the state will not get anything, even if it tends to be detrimental, because the state must pay for the sinking of the ship. So that with mediation, investigators prioritize auction options, grants, and other uses (as mandated also by the Regulation of the Minister of Finance of the Republic of Indonesia Number 03/PMK.06/2011 concerning Settlement of Seizure and Gratuities), because of these things the state benefits or income through Non-Tax State Revenues (PNBP).

Keywords: Fishery resources, Indonesia, IUU Fishing, protection, the concept of mediation.

Copyright (C) 2021 The Author(s): This is an open-access article distributed under the terms of the Creative Commons Attribution 4.0 International License (CC BY-NC 4.0) which permits unrestricted use, distribution, and reproduction in any medium for non-commercial use provided the original author and source are credited.

\section{INTRODUCTION}

Illegal, unreported and unregulated fishing (IUU fishing) practices have an adverse impact on the economy, ecology, sovereignty and social problems for Indonesia. According to FAO data, the economic losses experienced by Indonesia due to IUU Fishing range from Rp. 30 trillion per year. According to Suhana [1] direct economic losses result in reduced fishing contribution to GDP, reduced employment/loss in the fisheries sector, reduced state revenues from exports, reduced state revenues from the tax sector, absence of multi player effects from fishing industry activities. From the ecological aspect of IUU fishing, it has a negative impact on the destruction of fishery ecosystems due to overfishing that causes unsustainable fisheries development (sustainable fishers) [2]. From the ecological aspect of IUU fishing, it has a negative impact on the destruction of fishery ecosystems due to overfishing that causes unsustainable fisheries development (sustainable fishers). The social impact of IUU fishing is the conflict between traditional
Indonesian fishermen and foreign fishermen [3]. The sovereignty of the state can be violated because foreign fishermen enter Indonesian territorial waters without permission and committing criminal acts of fish theft [4]. Thus, the problem of IUU Fishing is a problem for many countries, not only for developed countries, but also for developing countries that feel the loss of this action.

Indonesia is a sovereign country, where a sovereign state has sovereignty to protect, manage and ensure that its sovereignty is not disturbed by other countries [5], whether on land, air or sea. The logical consequence of the existence of sovereignty for all countries is that the sovereignty of the country is not challenged even though it is only limited to intervention as mandated by the UN charter [6]. At the international level it is acknowledged that the world's capture fisheries activity continues to experience a very rapid increase which results in overfishing in several parts of the world's waters [7]. This phenomenon is also 
Mansur Armin Bin Ali., J Adv Educ Philos, Feb, 2021; 5(2): 52-57

followed by the increasing practice of IUU fishing that threatens the sustainability of fish resources and the environment. This condition encourages member countries of the Food and Agriculture Organization (FAO) to formulate references that can be applied by countries in the world regarding the management and development of fisheries in an orderly, responsible and sustainable manner. Among them is through The Code of Conduct for Responsible Fisheries (CCRF) which was agreed in 1995 [8]. In fact, this FAO formulation is used as a reference for countries in the world, especially for archipelagic countries in maintaining the sustainability of their fishery resource reserves.

Mediation is a method or means of resolving disputes, which has long been known in many religions or various cultures in the world. Various facts and or evidence have shown that basically mediation is not a foreign method for resolving disputes in the community. However, the concept and context of the approach and method are different, because it is more adapted to the local legal culture. Definition of Legal Culture according to Lawrence Friedmand, namely; “... People's attitudes toward law and the legal system of their beliefs, values, ideas and expectations. In other words, it is that part of the general culture which concerns the legal system" [9]. In this context, mediation is a dispute resolution option or a nonadjudication settlement, as a method and mechanism for peaceful dispute resolution or non-litigation [10]. We can learn the concept of mediation in China, in Chinese society there are 2 (two) types of dispute resolution outside the litigation or court system, namely mediation and arbitration, namely a method and process for resolving trade and maritime or maritime-fisheries disputes. Although the mediation procedure is more flexible, arbitration is commonly used. Usually Alternative Dispute Resolution (APS) or mediation is used to resolve international disputes such as international trade disputes, fishing in the exclusive economic zone, investment, financial projects, tender and auction issues, and projects related to construction. Initially, the APS system was not very popular, because what was better known was litigation [11]. The most important part of the mediation system that applies in China is people mediation, which significantly has several differences with the two other forms of mediation, namely:

a) Different mechanisms and implementation processes. At the People's mediation, everyone can ask for mediation at the basic government level (referred to as the village head) and it is carried out by the People's mediation committee, and administrative mediation, carried out by the authorized government official, while Court mediation is carried out by the ranks of the judiciary.

b) Different arenas of scope and/or habitat. In the People's mediation and Administrative mediation, it is not in the nature of litigation, or in accordance with the litigation procedure process whose procedures are regulated in the procedural law for civil cases and criminal cases that were sued for civil cases.

c) Different types of disputes can be mediated. In the People's mediation institution, it is possible to resolve all types of disputes that arise and those in society. Meanwhile, in Administrative mediation institutions, the types of disputes that can be handled are only limited to disputes that have been determined in statutory regulations. Whereas the Court mediation institution can mediate all types of disputes, both civil disputes in court and in the form or types of criminal disputes with civil suits.

d) Different from the results of the peace achieved. In the People's mediation, it has been regulated or measured as a result of the peace results achieved by the disputing parties, this is as regulated in Article 9 of the Organic Mediaton of the People's Mediation Committee, which states that the parties must comply with the contents of the peace agreement that has been agreed upon by by the People's Mediation Committee.

Thus, the decision of the People's mediation also has legal consequences which bind the parties directly. However, in the implementation instructions by the Minister of Justice on the decision of the Organic Mediation of the People's Mediation Committee, in order to have a binding and enforceable effect, an official decision from a government administration official or a court decision is still needed. Thus, in practice the People's Mediation cannot be final and legally binding, it only binds ethically and society's views. It is different from Administrative mediation and Court mediation which have definite legal consequences and are truly final and binding. If it is not carried out, then the aggrieved party can request its implementation through an administrative or court official for execution and/or to be carried out by force.

Mediation is an important effort for a country, especially an island nation, in protecting fishery resources from IUU fishing practices which damage the economy and the sustainability of its fishery resources. This paper specifically analyzes the concept of mediation as protection of fishery resources from IUU fishing practices in Indonesia

\section{RESEARCH METHOD}

The type of research used is normative legal research with a statutory approach [12], The data used are secondary data collected through literature search and document study. The collected data were then analyzed qualitatively [13] and then described.

\section{RESULTS AND DISCUSSION}

Internal sovereignty is the highest sovereignty possessed by the state to regulate, implement and enforce laws and regulations relating to fishery 
Mansur Armin Bin Ali., J Adv Educ Philos, Feb, 2021; 5(2): 52-57

resources in the jurisdiction of the state. External sovereignty means the sovereignty of the state to show its existence as a subject of international law, both in relation to the state and other international legal subjects related to fisheries [14]. Apart from China, we can also learn about the concept of mediation from Australia and Japan, which are considered successful in protecting fishery resources from IUU fishing practices.

Alternative Dispute Resolution (ADR). Nonlitigation dispute resolution in Australia such as in the field; In principle, industry, technology, fishery industry and society can be done through APS or Alternative Dispute Resolution (ADR) and or in particular through Mediation. As is the case with APS in general, APS or fisheries dispute settlement mediation in Australia can also be carried out either through litigation or through Alternative Dispute Resolution or brought in and carried out by peaceful settlement.

Alternative Dispute Resolution (ADR) or negotiation and mediation in Australia is supported by the government by providing consultation units and various forms of APS and mediation services according to the context and in synergy with the Australian judiciary. The Court shows and or directs a variety of cases suitable for mediation or settlement in Court. In addition, the New South Wales Supreme Court Alternative Dispute Resolution Steering Committee Referrals recommends an idea and thought that "no case is unsuitable for dispute resolution" and therefore any dispute resolution should be brought up. to be resolved through Alternative Dispute Resolution [15]. In terms of the use of mediation, before litigation is carried out on fisheries disputes, in general, in Australia, dispute resolution is carried out by mediation or amicably first. The settlement of disputes by mediation as in the legal context of the Anglo-Saxon countries is carried out based on the following principles [16]:

a) The principle of good faith;

b) The principle of prohibiting the use of force in dispute resolution;

c) The principle of freedom to choose methods of dispute resolution;

d) The principle of freedom of choice of law to be applied to the subject of the dispute;

e) The principle of agreement of the disputing parties (consensus);

f) The principle of first using national law for dispute settlement by APS (exhaustion of domestic remedies principle);

g) International legal principles concerning the sovereignty, independence and territorial integrity of states.

In Australia, if the parties use negotiation in the fisheries dispute settlement process, it is not successful, then the fisheries dispute resolution will be done through mediation. The mediation settlement will involve a third party selected by the disputing parties.
In Mediation the third party can be in the form of an individual or group, a country or group of countries or an international organization. In mediation, third countries not only make efforts for the disputing parties to meet each other, but also seek the basics of negotiations and take an active part in negotiations[17].

Whereas in Japan, dispute resolution is generally carried out through mediation, including fisheries dispute resolution, which has developed rapidly by involving many members of the community at large. The Minji-Chotei Institution is a dispute resolution procedure for Japanese society, where the parties in civil disputes, negotiate and seek settlement agreements that are in accordance with the rules of public thinking and in accordance with the real conditions of the dispute in question, by compromising one another, it can also be done by accepting intermediaries and/or assistance from a mediation/chotei institution that is managed by a court. Unlike litigation, where the court examines and assesses facts based on the arguments and tools and evidence presented by the parties themselves to determine whether or not the rights are prosecuted by implementing laws invite. Mediation (Chotei) is a process that can seek a dynamic, flexible, reasonable and appropriate resolution, which highly appreciates and assists in resolving disputes by the parties themselves independently, and without being strictly bound by certain procedural and material laws. The concept of mediation for fisheries dispute resolution in Japan takes the Chotei concept, which is the process of settling fisheries disputes before a lawsuit from either party. Chotei's request outside the litigation process (no lawsuit yet) in the Summary Court court with the help of the Conciliation Commissioners, which consists of 3 (three) people, and 1 (one) judge as chairman, (because now the judges are busy with so many cases, the position of the mediation judge can be filled by the advocate profession-based on changes to the Japan Civil Procedure Code January 1, 1998, April 21, 2004 with a term of office of 2 (two) years and can be reappointed), while 2 (two) non-judges as members consist of legal experts and/or professionals relevant technicalities, the selection of which largely depends on the type of case in dispute) [18].

In order for a mediator to work and carry out their duties properly, a mediator must understand what function he should play in a mediation process. Next, another writer, as quoted by Christopher, is Fuler, who here has also identified a number of functions that must be carried out by the mediator, namely [19]:

1. As a catalyst, which implies that the presence of a mediator in the negotiation process can encourage a constructive atmosphere for the discussion;

2. As an educator, it means that a person must try to understand the aspirations, work procedures, political limitations, and business constraints of 
Mansur Armin Bin Ali., J Adv Educ Philos, Feb, 2021; 5(2): 52-57

the parties. Therefore, he must try to be involved in the dynamics of differences between the parties;

3. As a translator, it means that the mediator must try to convey and formulate efforts from one party to another, through language or good expressions and gestures without reducing the targets achieved by the proposer.

Basically the joint fisheries development agreement has a different context from the Dokdo Island dispute. The island is a disputed territory and has added value to Japan and South Korea, while the Joint Fisheries Development Agreement is a sovereign activity of a country that is usually carried out in an undisputed maritime area. However, it should be borne in mind that although there has been no delimitation of a maritime zone in the Sea of Japan, Japan and South Korea both have territorial rights and sovereignty over the Sea of Japan area where these gas hydrate and fishery deposits are located. The Sea of Japan is the Exclusive Economic Zone of the two countries, so if joint fisheries development is carried out, it is not against the International Law of the Sea Convention, the joint fisheries development between Japan and South Korea does not include reclamation [20].

Mediation in the concept of protecting fishery resources from IUU fishing practice is by mediating IUU fishing cases that are being handled by law enforcement officials. According to the author's opinion, the large ships (such as the FV. Viking with a size of $1,322 \mathrm{GT}$ ) which were used as evidence in the IUU fishing crime should not be destroyed, but instead turned into state assets, the process of transitioning from evidence to state assets is carried out through a mediation process. This is in line with the Regulation of the Minister of Finance of the Republic of Indonesia Number 03/PMK.06/2011 concerning Settlement of Seizure and Gratuities. The AGO can take other options besides auction, including grants, destruction, and other uses, subject to the approval of the Minister of Finance. The option which is compatible with the drowning policy is of course the extermination option. The auction option so that it becomes a state asset also does not conflict with number 3 of the Attorney General's Letter of the Republic of Indonesia Number B.053/A/SKJA/03/2017 which instructs the Public Prosecutor (JPU) to file a claim for confiscation of the State against evidence of ships and equipment. others if they have not been destroyed at the investigation level. After the court decides that it is confiscated for the State and has permanent legal force, the Prosecutor chooses the option of carrying out the auction execution of the evidence by submitting an auction application to the Office of the State Wealth and Auction Service (KPKNL). KPKNL may not refuse the tender application submitted to him as long as the tender requirements documents are complete and have met the formal legality of the subject and object of the auction [21].
The policy of the Minister of Marine Affairs and Fisheries, Susi Pudjiastuti, to sink a foreign ship caught stealing fish in Indonesian waters, has again become the pros and cons. Various public responses were made to the policy. Including from the Indonesian Chamber of Commerce and Industry (Kadin). Deputy Chairman of the Indonesian Chamber of Commerce and Industry for Maritime Affairs and Fisheries, Yugi Prayanto, said that ex-foreign ships should be optimized to help fishermen rather than sinking them. He acknowledged that sinking illegal foreign fishing vessels is not entirely wrong as it has a deterrent effect on illegal fishing. There is a legal basis, namely Law Number 15 Year 2009 concerning Fisheries. However, he said, the step did not need to be extended. To sink a ship costs money too, not small. Why not just optimize it. The policy of sinking illegal foreign fishing vessels is indeed a dilemma because if you refuse, it is often considered not nationalistic. There is a report from Ambon, that fishermen do not need to go to sea because the fish are already there. But on the other hand, the industry has a shortage of fish supply due to insufficient (fleet) ships. So why isn't the ship optimized. Fishing boats purchased second hand from abroad have no longer been allowed to operate in the country. He suggested that the ex-foreign ships that were not sunk be handed over to fishermen through fishermen cooperatives. This was done so that the confiscated ships could continue to be used [22].

In line with this, according to the author's opinion, the policy of the Ministry of Marine Affairs and Fisheries of the Republic of Indonesia regarding the sinking of foreign vessels perpetrating IUU fishing is ineffective, because it only provides a temporary deterrent effect, while data in the field after being sunk still occurs IUU fishing by foreign vessels caused by the vast area of the Indonesian oceans. Besides that, the policy of sinking ships is very costly, while if it is confiscated and utilized by the state it is much more effective and efficient, especially for state revenue.

The benefit of mediation between the investigator and the ship owner is that the investigator does not take the option of destroying the confiscated evidence in accordance with Article 69 paragraph (1) and (4) of the Republic of Indonesia Law Number 45 Year 2009 concerning Amendments to Law of the Republic of Indonesia Number 31 Year 2004 Concerning Fisheries, which regulates that Paragraph (1) "Fishery control vessels function to carry out supervision and law enforcement in the fisheries sector within the fisheries management area of the Republic of Indonesia". Whereas in Paragraph (4) it is stipulated that "In carrying out the functions as referred to in paragraph (1), fisheries investigators and/or supervisors can take special actions in the form of burning and or sinking fishing boats with foreign flags based on sufficient initial evidence. 
Mansur Armin Bin Ali., J Adv Educ Philos, Feb, 2021; 5(2): 52-57

Instead, investigators take the option of auction, grant, or other use of ships, other equipment, and catch/fish to have benefits for the state, this is in accordance with the Regulation of the Minister of Finance of the Republic of Indonesia Number 03/PMK.06/ 2011 concerning Settlement of Confiscated Goods and Gratuities. Because the purpose of law besides justice is legal benefit and certainty. Meanwhile, the ship owner/criminal/IUU fishing perpetrator is involved in the mediation because the ship still belongs to the perpetrator (it's just that the state has confiscated it as evidence), and the ownership status has not been transferred to the state property.

Analysis in terms of norms, the mediation cannot be analyzed because the mediation here is novel in nature (the author's findings in the dissertation research) and there is no regulatory norm, therefore in order for this to be realized, the authors encourage the Supreme Court of the Republic of Indonesia to issue a Court Regulation (PERMA) to support this.

From a theoretical point of view, this mediation is possible even though IUU fishing is included in the criminal law regime, because in practice so far criminal cases have begun to be resolved through penal mediation. The existence of penal mediation found momentum when the Indonesian National Police issued the Chief of Police Letter No. Pol: B/3022/XII/ 2009/SDEOPS dated December 14, 2009 concerning Case Handling through Alternative Dispute Resolution/ADR which emphasizes the settlement of criminal cases using ADR as long as it is agreed by the parties in dispute.

The forms of ADR are summarized from several literature, are as follows:

- Consultation

- Negotiation

- Conciliation

- Mediation

- Arbitration

In the case of IUU Fisihing, the most suitable form of ADR is Mediation, where the mediator is the State Wealth and Auction Service Office (KPKNL) as an extension of the Indonesian Ministry of Finance (in this case the state).

The interest of the Mediator (state) is so that the evidence of fishery crime, in the form of (1) ships, (2) other equipment, and (3) the catch/fish has a beneficial value so that the investigator does not simply destroy it.

So that evidence has a beneficial value to the state so that it is endeavored to auction the money into the state as PNBP (Non-Tax State Revenue), or In order for evidence to have a beneficial value for fishermen, boats and other equipment are provided to cooperatives of fishermen groups so that they have a beneficial value for fishermen

\section{CONCLUSION}

In the future it is necessary to seek legal breakthroughs so that the IUU Fishing law enforcement process has benefits, the KPKNL as an extension of the Ministry of Finance of the Republic of Indonesia has an interest to streamline options other than annihilating (auctions, grants, other uses) so that it has benefits for the state to conduct mediation by how to bring together investigators (as representatives of the state, it is the state that is the victim of crime because they have suffered losses due to stolen fisheries resources) with the perpetrator/ship owner (the party who committed the crime) The importance of mediation is to prevent investigators from taking the option of sinking the ship (sinking the ship), because if this is done (the investigator takes the option to destroy), the state will not get anything, even if it tends to be detrimental, because the state must pay for the sinking of the ship. So that with mediation, investigators prioritize auction options, grants, and other uses (as mandated also by the Regulation of the Minister of Finance of the Republic of Indonesia Number 03/PMK.06/2011 concerning Settlement of Seizure and Gratuities), because of these things the state benefits or income through Non-Tax State Revenues (PNBP).

\section{REFERENCES}

1. Suhana. (2011). Ekonomi Politik Kebijakan Kelautan Indonesia: Gagasan-Gagasan PolitikPembangunan Negara Kepulauan Dan Reformasi Kelembagaan Yang Berbasis Kearifan Lokal, InTrans Publising, Malang, 76-77.

2. Akhmad, S. (2010). Politik Hukum Kelautan dan Perikanan: Isu, Permasalahan dan Telaah Kritis Permasalahan, Nuansa Aulia, Bandung, 44-45.

3. Suhana, 2011, Op.Cit., p. 77

4. Rokhmin, D. (2000). Orientasi Baru: Menoleh Ke Laut Dalam Pendayagunaan Kelautan Untuk Kesejahteraan Rakyat, Majalah LISPI (Lembaga Informasi dan Studi Pembangunan Indonesia), Jakarta, 2.

5. Kadarudin. (2020). Antologi Hukum Internasional Kontemporer, Deepublish, Yogyakarta, 492.

6. Mansur Armin Bin Ali, Bentuk dan Mekanisme. (2021). Perlindungan Hukum atas Sumber Daya Perikanan di Indonesia, Hermeneutika Jurnal Ilmu Hukum, 5(1).

7. Munadjat, D. (1982). Hukum Lingkungan Buku III Regional, Rosda Offset, Bandung, 53.

8. Ali, M. A. B., \& Rosdian, R. A. (2020). Implementation of Fisheries Resources Protection from Illegal Unreported and Unregulated Fishing Practices. Scholars International Journal of Law, Crime and Justice, 3(11), 389.

9. Lawrence, M. F. (1984). American Law: an Introduction, New York: W.W. Norlon \& Company, 4. 
Mansur Armin Bin Ali., J Adv Educ Philos, Feb, 2021; 5(2): 52-57

10. Efa, L. F. (2015). Pembaharuan Hukum Acara Perdata Suatu Keniscayaan dalam Penegakan Hukum Menuju Ketertiban Hukum, Orasi Ilmiah, disampaikan pada Penerimaan Jabatan Guru Besar Ilmu Hukum Acara, pada Fakultas Hukum Universitas Padjadjaran, Bandung.

11. The International Bank for Reconstruction and Development/The World Bank, Argentina Legal and Yudicial Sector Assesment, p. 64. Sebagaimana yang dikutip dalam Proceeding Court Annexed Mediation, 2011, p. 22.

12. Peter, M. M. (2005). Penelitian Hukum, Jakarta: Prenadamedia Group, 35.

13. Kadarudin. (2021). Penelitian di Bidang Ilmu Hukum (Sebuah Pemahaman Awal), Semarang: Formaci Press, 223.

14. Ali, M. A. B., Manuputty, A., Ashri, M., \& Hendrapati, M. (2018). State Authorization to Fishery Resources in Indonesia: Management and Conservation Effort. JL Pol'y \& Globalization, 73, 148 .
15. Nattan, H. (2001). "Alternatif Disputes Resolution", Paper, presented at a Training for Indonesian Judges by the Australian Federal Court in collaboration with ALRI and the Research and Development of the Supreme Court of the Republic of Indonesia.

16. Ibid.

17. Ibid.

18. Ibid

19. Ibid.

20. Ibid.

21. Article 13 Regulation of the Minister of Finance of the Republic of Indonesia Number 27/ PMK.06/2016

22. Kompas, Pro Kontra Penenggelaman Kapal, Ini Komentar Kadin", See https:/ekonomi.kompas.com/read/2018/01/10/203 236326/pro-kontra-penenggelaman-kapal-inikomentar-kadin. 